\title{
Decomposition and Seasonal Variation of Nutrient Composition of Mangrove Apoplankton in the Emerging Delta Island (Nayachar) of Hooghly River, West Bengal, India: Soil Microarthropods R.E.F
}

\author{
M. K. Dey, A. K. Hazra \\ Zoological Survey of India, New Alipore, Kolkata-53, India \\ mrinaldey@hotmail.com \\ mrinalkantidey86@gmail.com
}

\begin{abstract}
Mangrove leaf litter (Sonneratiaapetala) fall and decomposition was estimated using litter bags throughout the year(Pre

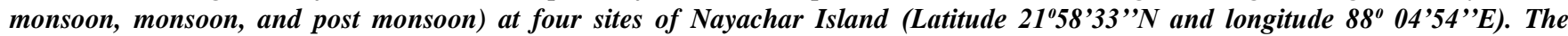
degrading leaf litter (Sonneratiaapetala) forms a high nutrient material that is consumed by a wide variety of organisms, specially soil microarthropods and release nutrients to the mangrove ecosystem for recycling as well. This study presents the decomposition rate for Sonneratiaapetala leaf litter throughout the year. It also quantifies physico-chemical factors along with microarthropods population abundance throughout the decomposition process. Soil microarthropods help ecosystem functioning by way of imparting important role of food chain, food-web system vis-a-vis in tropic relationships and also help nutrient cycling as decomposer. This study showed that breakdown of leaf litter was season and microarthropods population dependent.
\end{abstract}

Keywords: Decomposition, Sonneratiaapetala, Mangrove, Microarthropods

\section{Introduction}

Mangrove is a typical ecosystem in the intertidal area from tropical to subtropical muddy beaches worldwide. It has critical ecosystem functions such as coastal protection, land stabilization and $\mathrm{Co}_{2}$ fixation. It also provides important ecosystem services such as food, wood, Pharmaceutical production and other aesthetic value ${ }^{[1]}$. Sonneratiaapetala belongs to the family Lythraceae. It is locally known as "Keora". Sonneratiaapetala is a fast growing and pioneer tree species in ecological succession in the Sundarbans ${ }^{[2]}$. By modifying site condition, its facilities survival and establishment of next sere species which leads to the successful reclamation of many degraded mangroves forest ${ }^{[2]}$. Sonneratiaapetala isa very common tree in the NayacharIsland. This species usually colonizes on newly accreted mudflats of moderate to strong saline condition ${ }^{[3]}$. The degrading leaf-litter forms ahigh protein material that is consumed by a wide variety oforganisms and release nutrients to the mangrove ecosystem for recycling as well. Chemical and organic constituents of leaf litter of different species of mangroves was reported earlier [4-11] although reports of these components for litter from Sonneratiaapetala mangrove communities are limited. The present investigation also laid emphasize on the study of the decomposition process of Sonneratiaapetala leave litters and the succession of different microarthropods (Acarina, Collembola, Coleoptera, Diptera, Hymenoptera, Isopoda etc) population in different phase of decomposition at Nayachar Island on the river bay of Hooghly.

\section{Material \& Method}

Sonneratiaapetala mangrove plants were chosen for the study of mangrove leaves decomposition. Litter decomposition rate has been determined by litterbags methods. The litterbags were made of nylon, mesh sizes $\left(6 \mathrm{~mm}^{2}\right)$ were used for present study ${ }^{[12-13]}$. Freshly fallen leaves of different mangroves plant were collected from the mangrove belt of Nayachar Island(Latitude 21 ${ }^{\circ} 58^{\prime} 33^{\prime}$ ' $\mathrm{N}$ and longitude $88^{\circ} 04^{\prime} 54^{\prime}$ 'E). The leaves were chopped with size (1inch) into uniform lengths then dried in air. Each nylon bags was filled with $200 \mathrm{gm}$ air-dried litter. A set of 4 such bags was made for each selected sites. A total of $12(4 \times 3)$ bags were made in three different localities. Bags were placed at a depth 5 inch under the soil. The litter bags at the rate of decompose leaves were drawn at an intervals of 3 months for one year.Microarthropods from each litter bags were extracted by modified Tullgreen funnel ${ }^{[14-16]}$. The collected fauna were sorted out into different groups and identified with the help of Stereoscopic binocular microscope followed by taxonomic key. Decompose soil sample were study with the help of laboratory standard method ${ }^{[16]}$ and statistical analysis done by STATISTICA, Version 7.0. The study carried out in the coastal environment of West Bengal experienced three distinct seasons mainly determined by two major meteorological parameters (temperature and rainfall) each with four months duration viz. Premonsoon(March-June), Monsoon(JulyOctober), Postmonsoon(November-February) ${ }^{[17]]}$ (Nayachar IslandMap Source: Researchgate.net). 


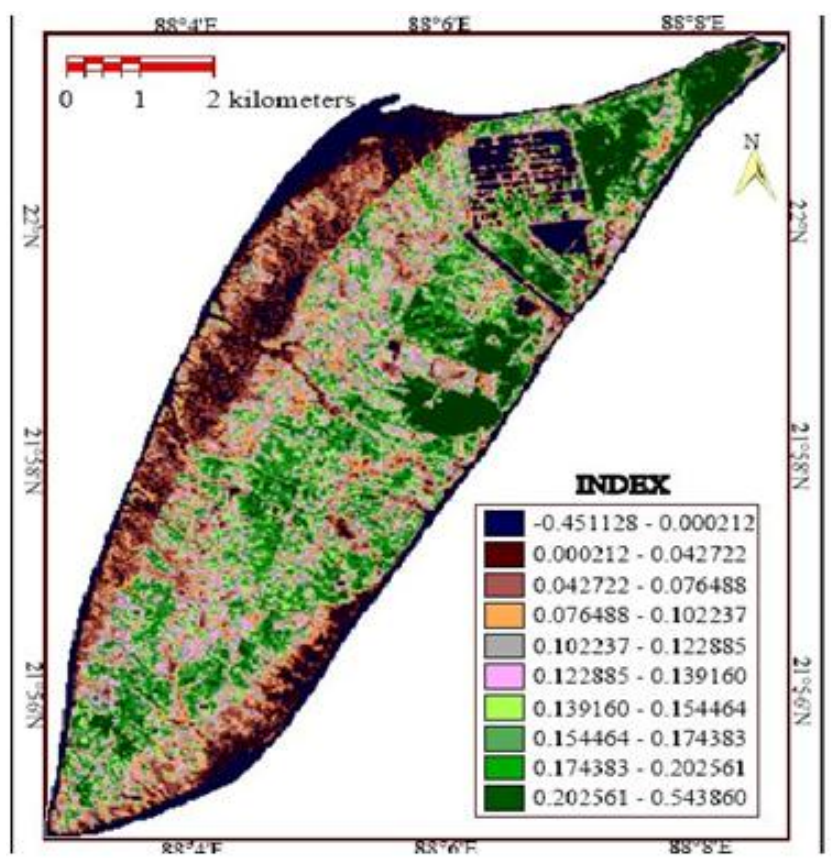

\section{Result \& Discussion}

Sonneratiaapetala, locally named as "Keora" an important species of mangrove was selected for litter decomposition study and the successional occurrence of different microarthropodal faunal components, rate of decomposition and changes of different physicochemical parameters associated with decomposing litters have been presented below

\section{a) Rate of decomposition}

The rate of decomposition of Sonneratiaapetala have been increased gradually from $3^{\text {rd }}$ month $(49.5 \%)$ and reached to $65.6 \%$ on the $6^{\text {th }}$ month, $73.67 \%$ on the $9^{\text {th }}$ month and $82 \%$ at the end of 12 months (Figure-1, 2 \& 3).

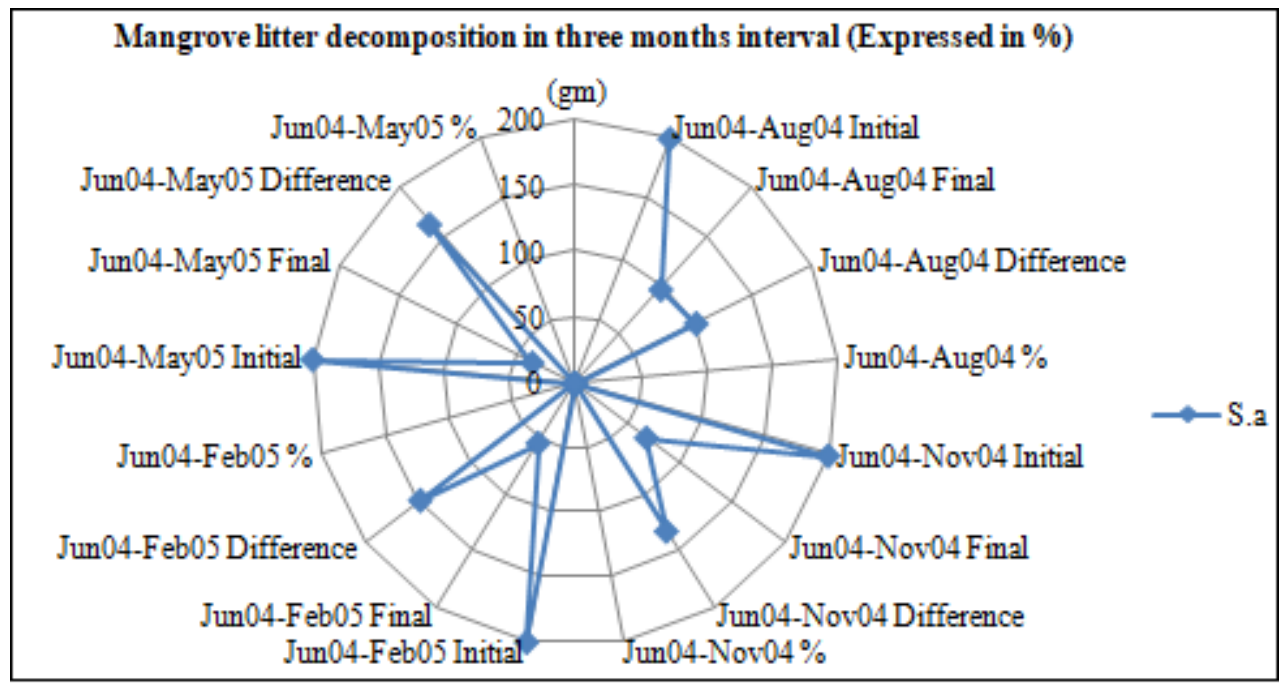

Figure 1

b) Faunal occurrence (Mean value) in different phases of decomposition

The number of different faunal groups when litter bags were withdrawn after 3 months were -Acarina(7), Collembola(8), Coleoptera (2), Diptera (2), Isopoda (1) and other microarthropods (2). After 6 months of decomposition of litter, the number of different faunal groups were - Acarina (120) ,Collembola (300), Coleoptera (4), Diptera (9.5), Isopoda (10), Hymenoptera(9) and other microarthropods (3). After 9 months, when the litter bags were withdrawn, the different faunal groups which were encountered wereAcarina (60), Collembola(120), Coleoptera (5), Diptera (4), Isopoda (5), Hymenoptera (6) and other microarthropods (1). At the end of 12 months when litter bags were withdrawn, Acarian (6), Collembola (7), Coleoptera (4), Diptera (4), Isopoda (7), Hymenoptera (8) and other microarthropods(3) constituted the litter faunal community (Figure-2 \& 3).

\section{c) Relative abundance (\%)}

Relative abundance of soil microarthropods revealed that after 3 months of decomposition, $\%$ of occurrence of Collembola was $36.36 \%$ followed by Acarina $(31.81 \%)$, Coleoptera (9.09\%), Diptera $(9.09 \%)$, other microarthropods $(9.09 \%)$ and Isopoda (4.54\%). After 6 months of decomposition, $\%$ of occurrence of Collembola was $65.78 \%$ followed by Acarina (26.31\%), Isopoda (21.9\%), Diptera $(2.19 \%)$, Coleoptera $(0.87 \%)$ and other microarthropods $(0.65 \%)$. After 9 months of decomposition, \% of occurrence of Collembola was $59.4 \%$ followed by Acarina (29.7\%), Hymenoptera (2.97\%), Coleoptera (2.47\%), Diptera (1.98\%) and other microarthropods $(0.99 \%)$. After 12 months of decomposition, $\%$ of occurrence of Hymenoptera was $20.51 \%$ followed by Collembola $(17.94 \%)$, Isopoda (17.94\%), Acarina (15.38\%), Coleoptera (10.25\%), Diptera $(10.25 \%)$ and other microarthrpods (7.69\%)(Table-1). 


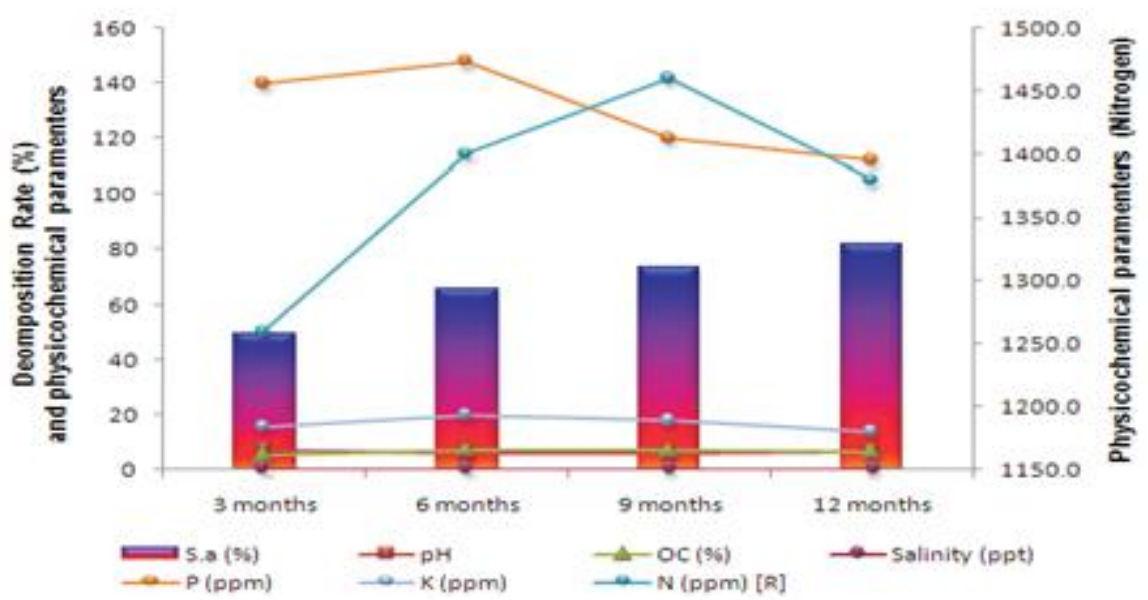

Figure 2: Density of soil microarthropods population with relation to physichochemicaparamentrs during different phases of decomposition of Sonneratiaapetala.
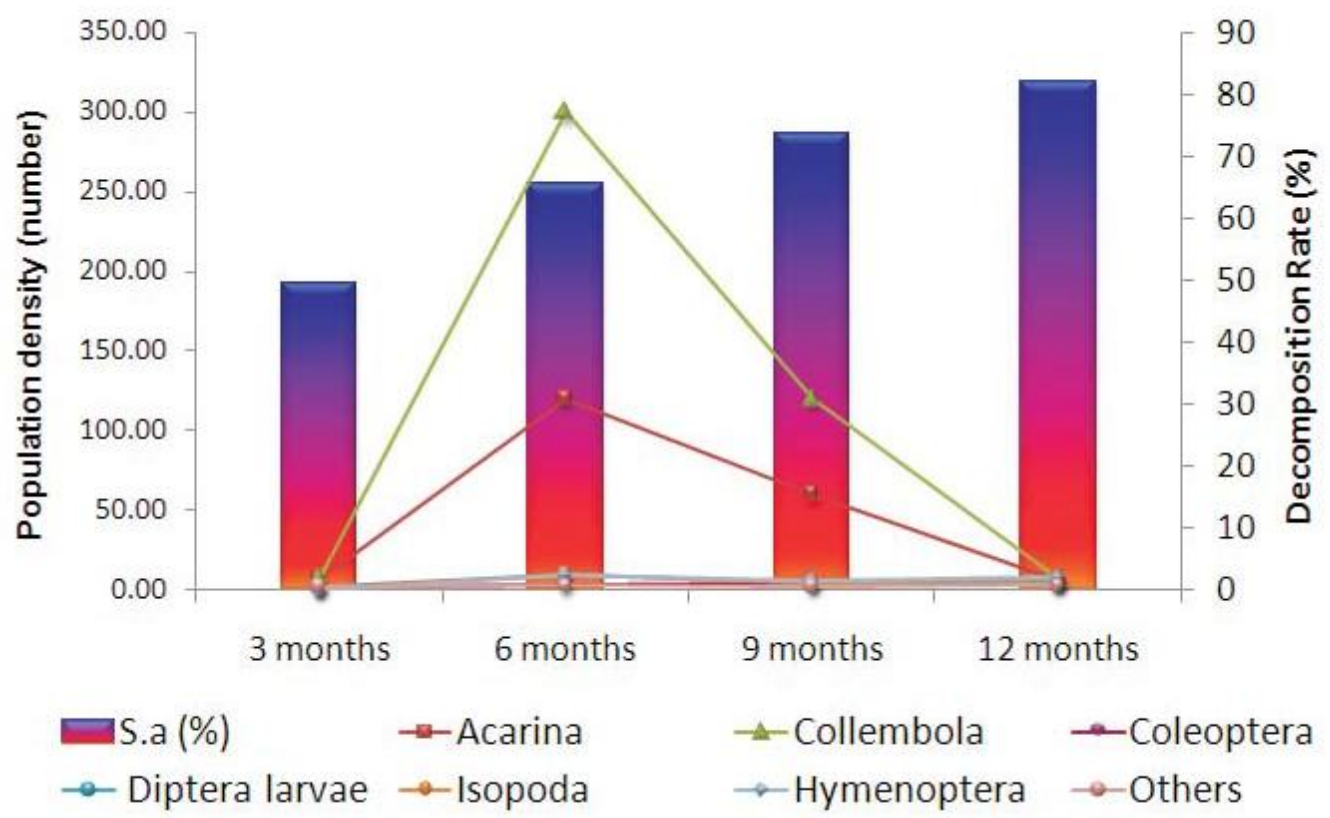

Figure 3: Different decomposition rate and with the occurrence of soil microarthropods population during different phases of decomposition of Sonneratiaapetala

d) Diversity of microarthropods in different phase's decomposition

During the yearlong (12 months) studies on litter decomposition, differential appearances of different group of microarthropods at different phase of litter decomposition were noticed. During the first phase (Initiation to 3 months), the Collembola population was found to be maximum followed by Acarina. On the $2^{\text {nd }}$ phase of decomposition ( 3 to 6 months), gradually different groups of microarthropods like Collembola and Acarina steadily increase their population while Diptera, Isopoda and Hymenoptera population marked its first appearance in the decomposing litters. In the $3^{\text {rd }}$ phase, the population density of Collembola and Acarina showed declining trend while the population density of Coleoptera, Diptera, Isopoda and Hymenoptera revealed an increasing trend. In the last phase ( 9 to 12 months), the population density of Acarina, Collembola, Diptera totally dwindled with maximum density of Isopoda and Hymenoptera(Figure.-3\&4) 


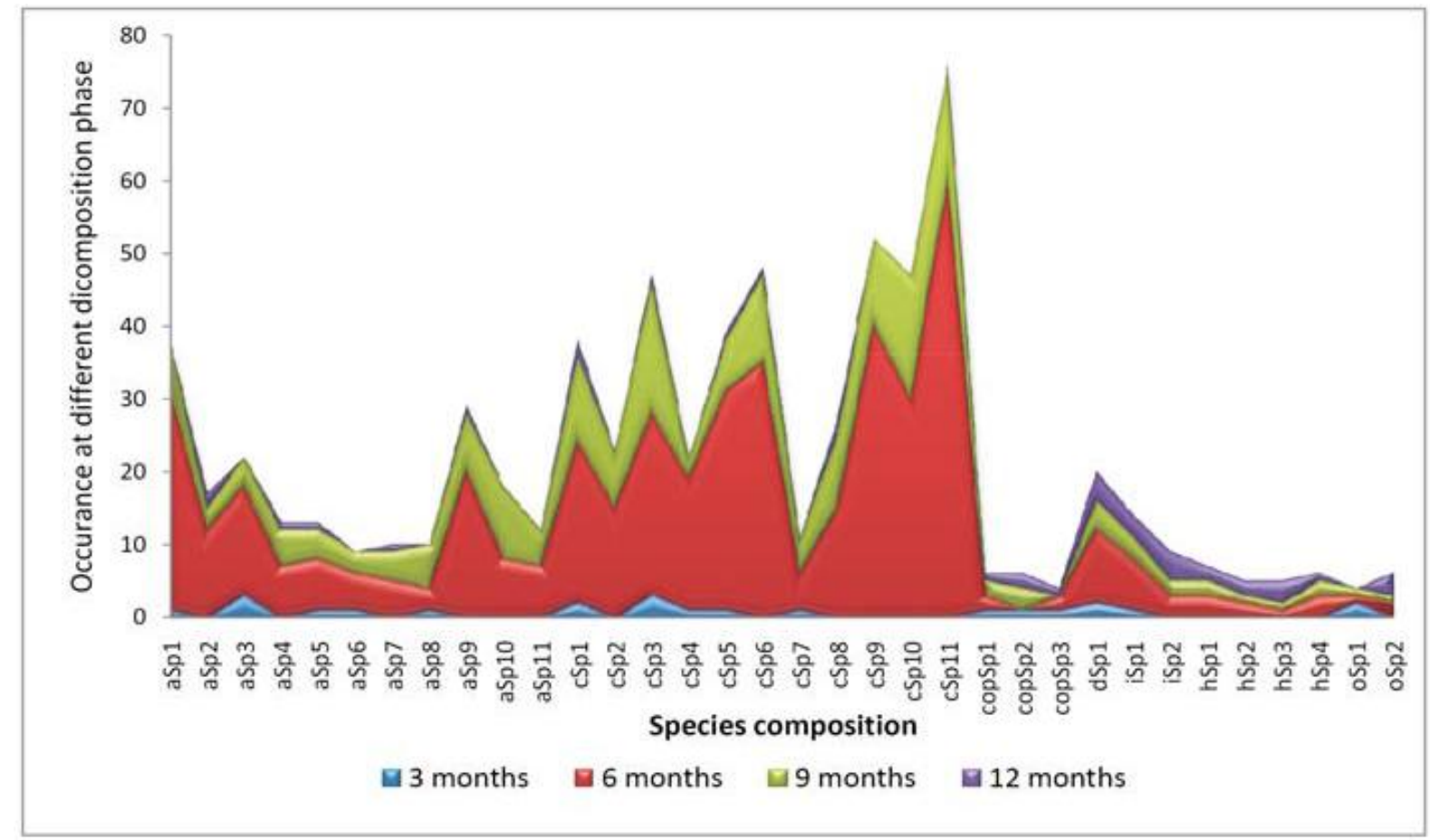

Figure 4: Occarance of difference microarthropods species during difference phases of litter decomposition of Sonneratiaapetala

e) Changes in the population density of different microarthropods species during different phases of decomposition

Fluctuation of population density of different microarthropods showed different trend in different phases of litter decomposition.

The definite population density started increasing after 6 months of decomposition of litter whereas their population density showed declining trend after 6 and continued upto 12 months of decomposition of litter. This category of microarthropod includes species like Scheloribatesthermophilus (asp1), Scheloribatesparvus (asp2), Schloribatespraeincisus(asp3), Xylobatesseminudus (asp4), Galumnaflabellifera (asp5), Oppiasp(asp6) , Multioppiasp (asp7), Tetocepheusvelatus(asp8), Tectocepheussp (asp9), Allonothrussp (asp10), Masthermanniasp (asp11), Isotomurusbalteatus (csp1), Isotomiella minor (csp2), Sminthuridesappendiculatus (csp3), Entomobryasp (csp4), Sinellasp(cs5), Lepidocyrtussp(csp6), Calxsp(csp7), Lepidocyrtusmedis (csp8), Proisotomasp (csp9), Mesaphorurachoudhuri (csp10), Sminthuridessp (cs11), Family Carabidae(cop1) and Pheidolaroberti (hsp4) ) (Figure-4).

The sharp population fluctuation of litter inhabiting microarthropod species viz. Family Dytiscidae(cop3), Mycetophilidae (dsp1), Philoscinsp(isp1), Procellionidessp (isp2), Monomorium destructor(hsp1), Monomoriumfloricola (hsp2) and Artemasp (osp1) where population density started increasing after 6 months of decomposition of litter while declining population trends registered after 9 months of decomposition and again an increasing trend of population was recorded after last phase (9 to 12 months) of decomposition of litter .
The marked population fluctuation of litter inhabiting microarthropods species viz.Monomoriumlatinode(hsp4) where population density started increasing after 6 months of decomposition of litter and these increasing trends was continued upto 12 months of decomposition of litter(Figure4)

\section{f) Physicochemical parameters during different phases of decomposition}

$\mathrm{pH}$ : Minimum $\mathrm{pH}$ (6) was recorded after 6 months of decomposition and maximum $\mathrm{pH}(7.4)$ was recorded after 3 months of decomposition period .Organic carbon $(\%)$ : Organic carbon showed its minimum (5.57\%) after 3 months of decomposition and maximum $(7.2 \%)$ was recorded after 6 months of decomposition period . Salinity (ppt): - Salinity was found lowest $(0.01 \mathrm{ppt})$ after 3 months of decomposition and that of highest $(0.11 \mathrm{ppt})$ was noticed after 9 months of decomposition period. Total Nitrogen ( $\mathrm{ppm}$ ): Total nitrogen showed its minimum value $(1260 \mathrm{ppm})$ after 3 months of decomposition and that of maximum value (1460ppm) after 9 months of decomposition period. Total phosphorus (ppm): Minimum total phosphorus (112ppm) was recorded after 12 months of decomposition and maximum (148ppm) was recorded after 6 months of decomposition period. Available potassium: Minimum available potassium (14ppm) was estimated after 12 months of decomposition and maximum (20ppm) was found after 6 months of decomposition period (Figure- 2 \& 3).

Different physico-chemical parameters of decomposing litters of mangrove, Sonneratiaapetala showed different results with regard to their positive and negative relationships with soil microarthropodd Only order Coleoptera showed significant positive correlation with total nitrogen (0.995) The species Oppiasp (asp6) showed significant positive correlation with available potassium (0.989), Sminthuridesappendiculatus displayed significant 
positive correlation with available potassium (0.964). Monomorium destructor (hsp1) exhibited significant negative correlation with $\mathrm{p} \mathrm{H}(-0.953)$ and significant positive correlation with organic carbon (0.967) (Table-1)

Table 1: Correlation between physicochemical parameters and different orders of soil microarthropods appeared in different phases of decomposition of mangrove plant litter (Sonneratiaapetala)

\begin{tabular}{|c|c|c|c|c|c|c|}
\hline Variable & $\mathrm{pH}$ & $\mathrm{OC}$ & Salinity & $\mathrm{N}$ & $\mathrm{P}$ & $\mathrm{K}$ \\
\hline \multirow{2}{*}{ Acarina } & -0.7786 & 0.6829 & 0.1449 & 0.5384 & 0.558 & 0.943 \\
\cline { 2 - 7 } & $\mathrm{p}=.221$ & $\mathrm{p}=.317$ & $\mathrm{p}=.855$ & $\mathrm{p}=.462$ & $\mathrm{p}=.442$ & $\mathrm{p}=.057$ \\
\hline \multirow{2}{*}{ Collembola } & -0.75 & 0.6588 & 0.0543 & 0.484 & 0.5964 & 0.9265 \\
\cline { 2 - 7 } & $\mathrm{p}=.250$ & $\mathrm{p}=.341$ & $\mathrm{p}=.946$ & $\mathrm{p}=.516$ & $\mathrm{p}=.404$ & $\mathrm{p}=.074$ \\
\hline \multirow{2}{*}{ Coleoptera } & -0.9008 & 0.9196 & 0.6623 & $.9950^{*}$ & -0.4727 & 0.3078 \\
\cline { 2 - 7 } & $\mathrm{p}=.099$ & $\mathrm{p}=.080$ & $\mathrm{p}=.338$ & $\mathrm{p}=.005^{*}$ & $\mathrm{p}=.527$ & $\mathrm{p}=.692$ \\
\hline \multirow{2}{*}{ Diptera } & -0.7558 & 0.7149 & -0.1809 & 0.453 & 0.4858 & 0.7407 \\
\cline { 2 - 7 } & $\mathrm{p}=.244$ & $\mathrm{p}=.285$ & $\mathrm{p}=.819$ & $\mathrm{p}=.547$ & $\mathrm{p}=.514$ & $\mathrm{p}=.259$ \\
\hline \multirow{2}{*}{ Isopoda } & -0.8436 & 0.8704 & -0.1325 & 0.6265 & 0.0735 & 0.4446 \\
\cline { 2 - 7 } & $\mathrm{p}=.156$ & $\mathrm{p}=.130$ & $\mathrm{p}=.868$ & $\mathrm{p}=.374$ & $\mathrm{p}=.926$ & $\mathrm{p}=.555$ \\
\hline \multirow{2}{*}{ Hymenoptera } & -0.8832 & 0.9369 & 0.0413 & 0.7641 & -0.2066 & 0.2882 \\
\cline { 2 - 7 } & $\mathrm{p}=.117$ & $\mathrm{p}=.063$ & $\mathrm{p}=.959$ & $\mathrm{p}=.236$ & $\mathrm{p}=.793$ & $\mathrm{p}=.712$ \\
\hline \multirow{2}{*}{ Others } & -0.441 & 0.5285 & -0.5774 & 0.2065 & 0 & 0 \\
\cline { 2 - 7 } & $\mathrm{p}=.559$ & $\mathrm{p}=.472$ & $\mathrm{p}=.423$ & $\mathrm{p}=.793$ & $\mathrm{p}=1.00$ & $\mathrm{p}=1.00$ \\
\hline
\end{tabular}

\section{Discussion}

Mangrove forests are among the world's most productive ecosystem, as well as unique wetland ecosystem in intertidal coastal regions of the tropics and subtropics ${ }^{[4-6]}$. Litter fall production and leaf litter decomposition are the principal factors for controlling the functions of mangroves to store and cycle carbon and nutrients within the ecosystem. Decomposition of litter contributes to the production of dissolved organic matter in the soil. Nutrient cycling starts when leaves fall to the ground and are subjected to microbial degradation [6]. Microbes such as bacteria and fungi contribute to the decomposition of mangrove materials, and to be transformation and cycling of nutrients. Processes of litterfall decomposition on mangrove forest floors are influenced by several parameters, including mangrove species, season, and position of the stand in the intertidal zone ${ }^{[18-19]}$. The most important components of all litter materials are the leaves; they can represent $40-85 \%$ of the litterfall $^{[9-10]}$. Among the biotic factors, the diversity and abundance of living organism have shown a high importance in the decomposition, especially for leaf tissue that have compounds that inhabit the action of predators and decomposition ${ }^{[11]}$. Leaf breakdown plays a key role in ecosystem function, species richness of leaf litter may be important in determining the nature of relationships between biodiversity and ecosystem properties ${ }^{[18-21]}$. The initial rapid weight loss rate were most likely due to the fast release of non-structural carbohydrates such as sugars and starches (dissolved organic materials) easily utilised by microbes ${ }^{\text {[22- }}$ 27] which subsequently colonised and initiated the breakdown of leaf material. Soil microarthropods like Collembola, Acarina, Coleoptera, Amphipods, nematodes, turbellarians, isopods were found to colonies in decomposed litterbags. Some of the soil microarthropods were the dominant group suggesting that they were relatively more important in enhancing litter breakdown.
The present work incorporated the study of enclosed selected mangrove (Sonneratiaapetala) litter in nylon mesh bags and an attempt to relate the activity of soil microarthropods over the season to the loss of litter weight during different phases of decomposition. The most of the abundant organisms in dry funnel extracts of decompose selected mangrove plant litter have been Collembola and Acarina and in most studies they are referred to as litter microathropods ${ }^{[27-35]}$. However, most of the other groups as included in the present study in addition to these two, came under the broad definition of this. The present investigation incorporated a detailed study of these microarthropods in relation to selected mangrove litter decomposition as the 6 $\mathrm{mm}^{2}$ mesh size of the nylon bags were used.

Maximum decomposition was recorded in 12 months and that of minimum was estimated during 3 months of decomposition periods. Maximum faunal occurrence was observed during 6 months of decomposition phase( post monsoon) whereas minimum faunal components were noted during 3 months decomposition phases(Pre monsoon). Maximum relative abundance of Collembola was recorded on 3 months; Acarina on $6^{\text {th }}$ months; Coleoptera on $9^{\text {th }}$ months and Isopoda on $12^{\text {th }}$ months of the decomposition. Maximum values of organic carbon, N, P, K. were recorded during $6^{\text {th }}$ month decomposition phases (Fig 2-3). Maximum number of total microarthropods occurred during the 6 months of decomposition phases, when organic carbon, $\mathrm{N}$, $\mathrm{P}, \mathrm{K}$ values also maximum yet, $\mathrm{pH}$ and salinity did not seen to play any role and the possible reason may be due to the minute range of fluctuation in litter bags (Table-1-2). However, it was seen that the organic carbon, N, P, K, in all the litter bags of Sonneratiaapetala plant's litters displayed significant positive relationship with the soil microarthropods which corroborated the findings of Gillikin, D. \& Verheyden, A. ${ }^{[22-25]}$, Hence the organic carbon, N, P, K, after leaching out from the litter, seemed to play a greater role in the regulation of microarthropods population. Correlation coefficient analysis between Collembola and ecological factors like N. P, K and organic carbon, showed significant positive correlation in most of the Sonneratiaapetala litter's decomposition in different sites of Nayachar Island. The present study revealed that though there was a succession of population in microarthropods, their role differed either individually or conjointly in litter decomposition. However, Gillikin, D. \&Verheyden, A. ${ }^{[24-25]]}$ were opined that metabolism, chemical decomposition of litter and microarthropods were less important compared with microflora . In the present study appearance and steady increase of Acarina, Collembola and Coleoptera population were found during the $1^{\text {st }}$ phase of decomposition. On the second phase of decomposition, gradually different groups of microarthropods viz. Acarina, Collembola, Coleoptera appeared and also displayed increasing trend in their population while Hymenoptera and other microarthropods started to record their appearance in the last phase of decomposition process. In the $3^{\text {rd }}$ phase, the population density of Acarina, Collembola and Coleoptera showed declining trend while the population density of Hymenoptera, Isopoda and other microarthropods revealed an opposite trend. In the last phase, the population density of Acarina, Collembola and Coleoptera totally dwindled with 
the recording of maximum density of Isopoda and other microarthropods (Fig 2-3and 4). The dynamic activities of soil microarthropods during different phases of decomposition (Sonneratiaapetala) were varied. The litter gets primarily broken down by Collembola and this partially decomposed litter gets acted upon by Acarina followed by Coleoptera, Diptera, Hymenoptera and other microarthropods. The correlation coefficient analysis revealed the organic carbon, $\mathrm{N}, \mathrm{P}, \mathrm{K}$ in all the litter bags of different selected study sites which revealed significant positive relationship with the soil microarthropods. In present study, Canonical correspondence analysis revealed that different ecological parameters of leaf decomposing litters (Sonneratiaapetala), soil and different decomposition rate have different intensity of impact on soil microarthropods faunal abundance. Overall findings of this study emphasizes that the different groups of soil microarthropods not only plays important role in litter decomposition (Sonneratiaapetala) simultaneously, they also plays important role in the nutrient cycling in the coastal environment of Purba Medinipur coastal area, West Bengal, India.

\section{Acknowledgement}

The authors wish and sincerely thank to Director, Zoological Survey of India, Kolkata for providing necessary laboratory facilities. Thanks are also Dr.A.K.Sanyal, Dr. Bulganin Mitra, Sri S.S.Saha, Sri K.K.Suman, Sri K.L.Nath, Sri B.K.Halder and other subject specialists of Zoological Survey of India.

\section{References}

[1] Saenger, P., Hegerl, E.J., Davie, J.D.S., (1983). Global Status of Mangrove Ecosystems. Commission on Ecology Papers. IUCE, The Netherlands, 66 pp.

[2] Chen, Y., Liao, B., Peng, Y., Xu, S., Zheng, S., and Chen, D. (2003). Researches on

[3] the northern introduction of mangrove species SonneratlaapetalaBuch.-Ham. Guangdong Forest. 19: 9-12.

[4] Troup, R.S.(1921). Silviculture of Indian Trees, vol. I, II. The Clarendon Press, Oxford.

[5] Lugo A.E, Snedaker SC. (1975) .Properties of a mangrove forest in SouthernFlorida. In Walsh G. Snedaker S. Teas H, editors. Proceeding of the international symposium on biology and management of mangroves. Gainesville. University of Florida, p170-212.

[6] Nagarajan B, Pandiarajan C, Krishnamoorty M, Sophia P. (2008) .Reproductive fitness and success inmangroves, implication on conservation . In Sengupta M , Dalwani R, editors . Proceeding of Taal 2007: the $12^{\text {th }}$ world Lake Conference, p29-33. International Lake Environment Committee Foundation held in Jaipur(India).

[7] Lee. K.H, Moran , M.K.Benner, R \&Hodson , R.E (1990) ; Influence of soluble components of red mangrove (Rhizophora mangle) leaves on microbial decomposition of structural (lignocelluosic) leaf components in seawatwr. Bull.Mar.Sci. 46. 374-386.
[8] Duke.N.C, Bunt, J and Williams , W (1981) Mangrove litter fall in north eastern Australia I. Annual totals by component in selected species . Austr. J. Botany 29. 547-553. Doi:10.1071/BT9810547

[9] Kristense, E, Bouillon S, Dittmar, T and Marchand C (2008). Organic carbon dynamic in mangrove ecosystem a review . Aquat. Bot. 89, 201-219. Doi: 10.1016/ j-aquabot.2007.12.005.

[10] Mackey. A and Small, G (1996) . The decomposition of mangrove litter in a subtropical mangrove forest Hydrobiology 332, 93-98. Doi: 10.1007/BF00016688.

[11] Ochieng, C.A and Erftemerjer, P.L (2002) Phenology, litterfall and nutrients resorption in Avicennia marina (Forssk) Vierh in Gazi Bay, Kenya Trees 16, 167-171. Doi :10.1007/s00468-001-0146-2.

[12] Chapin III, F.S, P.A Matson \& H.A .Mooney, (2002) Principles of terrestrial ecosystem ecology. Springer New York , 436pp

[13] Kuhnelt, W.( 1963). Soil inhabiting arthropods. Ann.Rev. Entomol,8: 115-136.

[14] Anderson, J. M. (1973). The breakdown and decomposition of sweet chestnut (Castaneastiva Mill) and beech (Faqussylvatica L.) leaf litter in two deciduous woodland soils. 1. Breakdown, Leaching and decomposition. Oecologic (Berl.)12 : 251-274.

[15] Macfadyen, A. (1955). A comparison of methods for extracting soil arthropods, 315-332. In: Soil Zoology (D.K.McEKevan, Ed.) Butterworth, London.

[16] Strickland, J.D. and Parsons, T.R. (1968). A practical handbook of seawater analysis. Fish. Res. Bd. Can. Bull. No.167: 57-143.

[17] Walkey, A. and I.A. Blacks, (1934). An examination of the Degtjareff method for determining soil organic matter and a proposed modification of chromic acid titration method . Soil.Sci. 37: 29-38

[18] Chaudhuri, A.B. and A. Chaudhuri. (1994). Mangroves of the Sundarbans volume one. India. IUCN-The World Conservation Union. P.36.

[19] Duke, N.C J, Meynecke , O.Dittmann, S. Ellison, A.M and Anger K (2007). A world without mangrove? Science317, 41-42 doi 10.1126/science 317.5834.41b.

[20] M.K.DEY, A.K.HAZRA AND S.K.CHAKRABORTY (2008) Diversity of Microarthropods and the Plant Litter Decomposition in the Coastal Tract of East Midnapore District, West Bengal, India. Zoological Research in Human Welfare :20; 207-226 . ISSN-0373-5893.

[21] M.K.DEY, A.K.HAZRA AND S.K.CHAKRABORTY (2010) Functional Role of Microarthropods in Nutrient Cycling of Mangrove Estuarine Ecosystem of Midnapore Coast of West Bengal, India. International Journal of Environmental Technology and Management. Vol12 No1; 67-84 ISSN-1466-2132.

[22] M.K.DEY, A.K.HAZRA AND S.K.CHAKRABORTY (2006) Ecology of Coliform Bacteria in a Heavy Metals Contaminated River at Midnapore District area, West Bengal. Rec.Zool.Surv. India (Part-3); 1-8. ISBN-81-8171-0649.

[23] Kristensen .E, Bouillon .S, Dittmar , T, and Marchand , C (2008). Organic carbon dynamics in 
mangrove ecosystem a review . Aquat.Bot. 89, 201219. Doi: 10.1016/J.aquabot.2007.12.005.

[24] Wardle, D.A.; K.I. Bonner and K.S. Nicholson, (1997). Biodiversity and plant litter; experimental evidence which does not support the view that enhanced species richness improves ecosystem function. Oikos 79: 247-258.

[25] M.K.DEY, A.K.HAZRA AND A.K.SANYAL (2005). Effect OF Soil Salinity On The Population Dynamics Of Soil Arthropods Fauna at Nayachar Island Of MidnaporeDistrict .Environment \& Ecology: 23(4); 767-769.ISSN-0970-0420.

[26] M.K.DEY \& A.K.HAZRA (2020). Litter fall and decomposition of Mangrove species (Excoecariaagallacha ) in a newly emerged Island (Nayachar ). West Bengal. India; w.r.f Soil microarthropods. International Journal of Innovative Science and Research Technology : ISSN No 2456-2165; Vol 5.

[27] Sjoling S, Salim M, Thomas J, Jasson J.K (2005) . Journal Estuarine Coastal and Shelf Science 63: 397406.

[28] Gillikin, D. \&Verheyden, A. (2005). "RhizophoramucronataLamk. 1804". A field guide to Kenyan mangroves

[29] Chapman, S.B (1986). Production Ecology and Nutrient Budgets In,Moore ,P.D \& Chapman, S.B. Methods in plant ecology. Second Edition, Oxford, Blackwell Scientific Publication. 1-59pp.

[30] M.K.DEY, A.K.HAZRA AND S.K.CHAKRABORTY (2012)Diversity Of Mangrove Litter Inhabiting Microarthropods with Special Reference To Their Functional Role in Midnapore(East) Cosast, West Bengal, India . Biodiversity \&Taxonomy, Narendra Publishing House . pp29-42. ISBN 978-93-80428925.

[31] M.K.DEY \& A.K.HAZRA (2020) • Litter decomposition Study (Aveicenniaoffcinalis) with the help of soil arthropods. W.r.f to Nayachar Island, West Bengal, India . International Journal of Science and Research. ISSN: 2319-7064. Vol 9; Issue 10 Oct.

[32] M.K.DEY \& A.K.HAZRA (2020). Heritierafomes (Buch-Hum) leaf litter decomposition of newly emerged virgin deltaic Island (Nachar) located on north eastern part ofMidnapore coast of West Bengal . International Journal of Creative research thoughts. ISSN 2320-2882. Vol-8.

[33] Raffaelli, D \& Hawkins, S (1996). Inertidal Ecology . $1^{\text {st }}$ edition, Londres, Chapman and Hall .356pp.

[34] Gillikin, D. \& Verheyden, A. (2005). "Rhizophoramucronata Lamk. 1804". A field guide to Kenyan mangroves

[35] M.K.DEY, A.K.HAZRA AND S.K.CHAKRABORY (2007) Soil Micro-Arthropods Population in Alluvial and Coastal Soil InMidnaporeDstrict With Special Reference To Relative Abundance. Rec.Zool.Surv.India; 107(Part4):93-99. ISBN 81-8171-0649.

[36] M.K.DEY, A.K.HAZRA AND G.P.MANDAL (2005) Diversity And Distribution of Arthropods Fauna In Relation To Mangrove Vegetation On A Newly Emerged Island On The River Hooghly, West
Bengal. Rec. Zool.Surv. India. 104(Part3-4); 99-102. ISBN-81-8171-0649. 